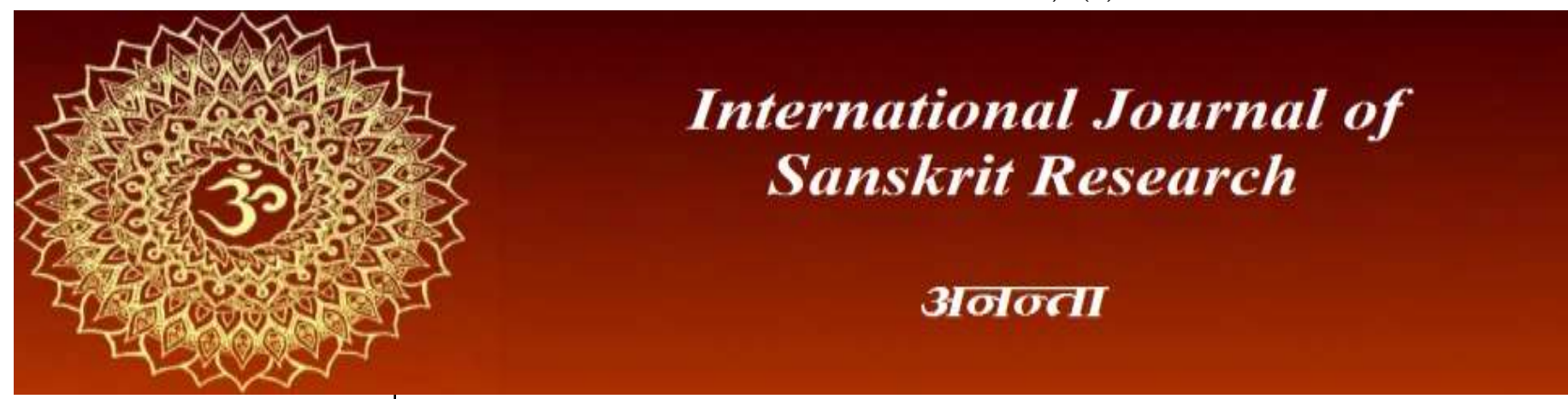

ISSN: 2394-7519

IJSR 2021; 7(5): 264-266

(C) 2021 IJSR

www.anantaajournal.com

Received: 22-07-2021

Accepted: 16-08-2021

Dr. Mausumi Goswami

Assistant Professor,

Department of Sanskrit,

K. K. Handique Govt. Sanskrit

College, Guwahati, Assam, India

\section{Environmental consciousness as reflected in the vedas}

\section{Dr. Mausumi Goswami}

DOI: https://doi.org/10.22271/23947519.2021.v7.i5e.1513

\section{Abstract:}

Without environment the existence of human being can never be imagined. Human are dependent on nature. There was a very close relation between men and nature since the time of inception. This relationship made human being more conscious about their environment and its protection in which they dwelled. Thus it can be said that Environmental consciousness is an age old phenomenon of human civilization. It has seen reflected in the pages of the Vedas, which are the earliest literary monumental works of the Hindus. The Vedic seers could realize the fact that the harmonious relation between the environment and the living creatures is much beneficial for the entire globe. Nature-worship was one of the prime duties of the people of the Vedic age. In the midst of nature the ancient Indian cultures have grown and due to this reason the ancient Indians had a great admiration for environment. Since then with utmost devotion and sincerity they had worshipped various objects of nature. In fact, they attribute divinity to nature. In this way this vast literature incorporates ample references on protection and conservation of environment. In the present paper an attempt has been made to highlight the awareness of ancient Indian people about environment.

Keyword: Vedas, environment, air, water, protection

\section{Introduction}

In general sense of the term, environment can be called as our surrounding. It surrounds the human beings from all sides. Environment is defined by the Environment Protection Act, 1986, as follows, 'Environment includes water air and land and the inter-relationship which exists among and between water, air and land and human beings, other living creatures, plants, microorganisms and property' ${ }^{[1]}$. According to Oxford Advanced Learner's Dictionary, environment is 'the natural world in which people, animals and plants live' ${ }^{[2]}$. The study of environment as a branch of modern science was first established in the $20^{\text {th }}$ century. But, it's root can be traced back in to the Vedic Literature. The Sanskrit term used for environment is paryāvarana. Paryāvarana is derived from the root $v r$, which means to cover. The root $v r$ preceded by the indeclinable 'pari' and ' $\bar{a}$ ' with the suffix 'lyut' forms the word paryāvarana. Thus it means -- paritah samyak vrnoti ācchādayati iti paryāvaranam that which surrounds us from all the sides is called Paryāvaranam.

In the Atharvaveda we have come across different equivalent words of environment, viz., $v r t \bar{a} v r t \bar{a}^{[3]}$, abhīvarah ${ }^{[4]}, \bar{a} v r t \bar{a}^{[5]}$, parīvrtā ${ }^{[6]}$ etc. The seers of the Atharvaveda have defined the Vedic concept of environment where chandāinsi is referred to denote the three coverings of our surroundings. Thus, the Veda reads,

\section{trīni chandānisi kavayo vi yetire pururūpam darśatam viśvacakṣhaṇam/ āpo vāta aușadhayastānyaekasmin bhuvan arpitāni//}

The meaning of the verse is, "wise utilize three elements variously which are varied, visible and full of qualities. These are water, air and plants or herbs. They exist in the world from the very beginning. They are called as chandāinsi meaning coverings available everywhere." 7 This verse implies the fact that Vedic seers were well acquainted with the basic constituents of environment.
Corresponding Author: Dr. Mausumi Goswami Assistant Professor,

Department of Sanskrit, K. K. Handique Govt. Sanskrit College, Guwahati, Assam, India 


\section{Objectives of the Study}

- To find out the environmental issues described in the Vedas.

- To highlight the significant Vedic environmental concepts related to present context.

\begin{abstract}
Methodology
In the present study analytical method has been used. We propose to rely upon both primary and secondary data. The primary data are collected from the original Vedic texts, their commentaries and for secondary data various books, research reports, articles, journals have been consulted.
\end{abstract}

\section{Attributing Divinity to Nature}

The people of the Vedic age showed deep respect for the environment especially to the nature. The Vedas contain such hymns which suggest the importance of various natural resources. They are mainly concerned with the concept of nature-worship and attributed divinity to it. The four constituents of environment namely, earth, water, fire and air which provide the bases of life, are considered sacred entities by the Vedic seers and accordingly worshipped them as divine beings.

\section{Constituents of Environment}

The oldest of the four Vedas, the Rgveda contains several hymns which are dedicated to nature and natural forces. The Gods addressed in those hymns are under the influence of the most impressive phenomenon of nature and its aspects. In those hymns we find prayers for certain natural elements such as air, water, earth, sun, rain, dawn etc. According to the Aitareya Upanișad, the whole world consists of five basic elements, viz., earth, water, light, air, and ether ${ }^{[8]}$. A balance has been maintained by the nature between these constituents of environment and living beings. A slight change in any one of these constituents results in natural imbalance and as a consequence the living beings have to face lots of troubles.

Earth is considered as one of the prime environmental constituent. From the environmental point of view the importance of earth is greater because it is the base of all other constituents of nature. It has seen that the Vedic seers have given a much esteemed position to mother earth. The famous Bhümisūkta or Prithivīsūkta of the Atharvaveda reflects the environmental consciousness of Vedic seers. As an ideal mother becomes ever ready to fulfill the desires of her offspring, similarly mother earth is also keen to fulfill the desires of all the living beings just like her own children. Hence, the Vedic seers utter "mātā bhūmih putro'ham prithivyāh" that means, Earth is my mother, I am her son ${ }^{[9]}$. Earth is well- known for her natural gifts, and mostly for herbs and vegetation. It is revealed in the Bhümisūkta that we should not unnecessarily dig the earth, instead we should preserve her. Thus the Atharvaveda reads,

\section{yat te bhūme vikhanāmi kṣhiprami tadapi rohatu/ mate marma vimrgvari mā te hrdayamārpipaí///10]}

The Rgvedic seers also pray Earth as mother, "dyaurme pitā janitā nābhiratra bandhurme mātā prithivī mahīyam" "[11]. In one verse of the Atharvaveda mother earth is prayed to make the mountains and trees free from pollution so that people can live happily ${ }^{[12]}$.

Water is the most essential element for every life on the world. The ninth hymn of the tenth mandala of the Rgveda is dedicated to water. There it is stated that as a mother provides nutrition by feeding her child, in the same way water may also give us nutrition ${ }^{[13]}$. The Rgveda reveals that there are five sources of natural water, i.e., divyah (rain water) śravanti (natural stream), khanitrimāh (wells and canals) svayamjah (lakes), and samudrarthah (rivers) ${ }^{[14]}$. According to the Atharvaveda there are eight types of water, viz., haimavatī, (river water which come down from himalayā) utsyāh, (in the form of waves) sanisyadā, (always flowing) varșyā, (rain water), dhanvanya $\bar{a}$, (water in desert) anupyāh, (water receive from holes)) khanitramā, (wells and canals) kumbheyih (water kept in vessel) ${ }^{[15]}$. Śatapatha Brāhmaṇa refers to seventeen

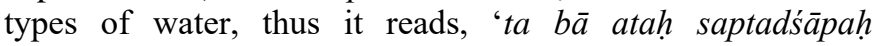
sambharanti saptadaśo vai prajāpatih' ${ }^{[16]}$.Chāndogya Upanishad refers to various qualities of water ${ }^{[17]}$. The cycle of water is described in the Atharvaveda where it is stated that from ocean waters reach to sky and from sky come back to earth ${ }^{[18]}$. Polluting of water is strictly prohibited in the Yajurveda. Thus it reads, 'mā āpo himsir' ${ }^{[19]}$. The Vedic seers were aware of importance of water for life. Waters are source of all plants and giver of good health ${ }^{[20]}$. It destroys all kind of diseases ${ }^{[21]}$.

Sun is the main source of energy on this earth. The rays of sun drive away all the negativity which exists in the nature. Due to this reason sun is worshipped as divine being in almost all the cultures of the world. Sun not only purifies the environmental pollution but its rays are very much beneficial from the point of medical science also. Vedic seers have revealed that sun increases life span, energy and intelligence of human being. Sun rays contain vitamin D which has positive impact on human body. Considering this, the Vedic seers have prayed sun to remove heart disease along with all other diseases of people ${ }^{[22]}$.

Another life giving element of nature is $v \bar{a} y u$ or air. Air is a vital constituent of nature. The Vedic seers knew the significance of air for the survival of living beings. They were well aware about the air exists in atmosphere as well as the air which resides inside the body. According to the Taittiriya Upanishad there are five types of wind within the human body, viz., prāna, (air flowing forward), apāna, (regressing air) udāna, (upward moving air) samāna ( balanced air) and vyāna, (air flowing outward) ${ }^{[23]}$. The Rgvedic seers have prayed air as father and protector [24]. Vedic seers have revealed that the wind blow in the form of medicine may confer happiness and welfare upon us ${ }^{[25]}$. They realized the fact that only in pollution free environment healthy and long life is possible.

The importance of $\bar{a} k \overline{a s} a$ or ether is openly mentioned in the verses of the Vedas. In the Yajurveda the seers have appealed to all living being to stay away from doing any kind of harm to the sky and not to pollute the sky ${ }^{[26]}$. Sun shines in Dyuloka and thus people get light from sky. The sun rays help in strengthening our inner power which is essential for living.

\section{Rta the cosmic law}

The universal law which governs everything in the cosmos is called as Rta. It is a great 'cosmic order' which is the regulating power of the world and also cause of all motion and existence. Everyone is under this law of Rta; even gods are born of it. Due to Rta sun shines in sky ${ }^{[27]}$. The whole of the manifested universe is working under Rta. Varuna is portrayed as the lord of Rta in the Vedas. He is law-maker, a great king, moral governor and leader of the universe. Only because of Varuna's rule, moon shines and moves at night, stars seen only at night, rivers flow so son and so forth. In this way the Vedic seers have depicted Varuna as a controlling force of the Universe. 
The Rgvedic seers have referred to the presence of a protective layer. This layer is now known to be the ozone layer. This ozone layer filters the harmful rays of the sun and protects the earth. It absorbs the rays which are harmful for the environment. The twin god Aśvins are prayed by the Rgvedic seers to protect the living beings from the excessive solar flame that influences the temperature of the earth.

\section{Plants and Herbs}

Vedic literature contains several references regarding the origin and importance of plants. The Aranyānisūkta incorporated in the Rgveda is addressed to the deity of forest [28]. The Vedic seers highly praised Aranyāni, the queen of the forest, not only for her gifts to human being but also for her splendor. There is another hymn in the Rgveda named as Oșhadhisükta in which plants and vegetables are addressed as mother ${ }^{[29]}$. The Atharvaveda refers to different Oșhadhis along with their values, later on this information became a very significant source for the Ayurveda. In the Atharvaveda there is a reference of ' $a v i$ ' element which is the cause of greenness of trees ${ }^{[30]}$. It is considered as chlorophyll by the Vedic scholars.

\section{Birds and animals}

Animals and birds are inseparable elements of nature. It has seen that the Vedic seers were desirous of the welfare of the birds and animals. Vedic people were much concerned about the wellbeing of their cattle, cows, horses etc. The cow occupied a very significant position in the life the Vedic people. It was considered as a symbol of prosperity and wealth. The Vedic seers had soft corners towards animals, they wished that animals should be healthy, safe and protected [31]. Human being along with both the domestic and wild animals should live peacefully being controlled by the gods like Rudra, Pușan etc.

\section{Conclusion}

From the above discussion it can be said that the Vedic seers were very much aware about the environment and its preservation. Along with the human beings they attached great importance to all other components of nature, viz., land, air, water, animals, birds, and plants and emphasizes upon their preservation, nourishment and protection. Vedic thoughts have encouraged people to live harmoniously with the elements of environment. Vedic seers believed that any kind of imbalance between this two can cause trouble for the survival of living beings. They were desirous of living a life of hundred years. Hence, they have uttered, 'jivema śaradah śatam'. ${ }^{32}$ It indicates that during those days environment was free from pollution. Vedic seers believed that the environment is for all living beings in the universe so it should be protected with utmost care.

\section{References}

1. Panchmukhi AR. Socio-economic Ideas in Ancient Indian Literature, Rashtriya Sanskrit Sansthan, Delhi 1998, p.467.

2. Oxford Advanced Learner's Dictionary, Oxford University Press, $8^{\text {th }}$ Edition, p.510.

3. AV., $12 / 1 / 52$

4. Ibid., $1 / 32 / 4$

5. Ibid., 10/1/30

6. Ibid., 10/8/31

7. Ibid., $18 / 1 / 17$

8. AU., $3 / 3$
9. AV., $12 / 1 / 12$

10. Ibid., $12 / 1 / 35$

11. RV., $1 / 164 / 33$

12. girayaste parvatā himavanto'ranyam te prithivī syonamastu/ AV., 12/1/11

13. RV., 10/9/1,2,3

14. Ibid., $7 / 49 / 2$

15. AV., $19 / 2 / 1,2$

16. SB., $5 / 3 / 4 / 22$

17. CU., $7 / 10 / 1$

18. āpah samudrād divamudvahanti divasprthivīmadhi ye srjanti/AV., 4/27/4

19. YV., $6 / 22$

20. āpaḥ viśvabheșajụh/RV., 1/23/20

21. bheșajūrāpo amīvcātaniḥ/Ibid., 10/87/6

22. RV., $1 / 50 / 11$

23. TU., $2 / 4$

24. uta vāta pitāsi nạ̣/ ṚV., 10/186/2

25. vāta ā vātu bheșajam śubham mayobhu nu hṛde/ Ibid., 10/186/1

26. YV., $5 / 43$

27. RV., 10/85/1

28. Ibid., 10/146

29. Ibid., 10/97/2

30. avirvai nāma devataternāste parīvṛtā/ tasyā rūpeneme vṛkṣhā haritā haritasrajaḥ// AV., 10/8/31

31. YV., 19/20

AV., 11/2/24

32. AV., 19/67/1 